\title{
Regulation of tert-Butyl Hydroperoxide Resistance by Chromosomal OhrR in A. baumannii ATCC 19606
}

\author{
Shih-Jie Chen ${ }^{1,+}$, Hung-Yu Shu ${ }^{2,+} \mathbb{( D}$ and Guang-Huey Lin $1,3, *$ (D) \\ 1 Master Program in Microbiology and Immunology, School of Medicine, Tzu Chi University, \\ Hualien 97004, Taiwan; 105329103@gms.tcu.edu.tw \\ 2 Department of Bioscience Technology, Chang Jung Christian University, Tainan 71101, Taiwan; \\ hyshu@mail.cjcu.edu.tw \\ 3 International College, Tzu Chi University, Hualien 97004, Taiwan \\ * Correspondence: veronica@gms.tcu.edu.tw or guanghuey@gmail.com \\ + S.-J.C. and H.-Y.S. contributed equally to this work.
}

Citation: Chen, S.-J.; Shu, H.-Y.; Lin, G.-H. Regulation of tert-Butyl Hydroperoxide Resistance by Chromosomal OhrR in A. baumannii ATCC 19606. Microorganisms 2021, 9 , 629. https://doi.org/10.3390/ microorganisms 9030629

Academic Editor: Maurizio Falconi

Received: 13 February 2021

Accepted: 15 March 2021

Published: 18 March 2021

Publisher's Note: MDPI stays neutral with regard to jurisdictional claims in published maps and institutional affiliations.

\begin{abstract}
In this study, we show that Acinetobacter baumannii ATCC 19606 harbors two sets of ohrR-ohr genes, respectively encoded in chromosomal DNA and a pMAC plasmid. We found no significant difference in organic hydroperoxide (OHP) resistance between strains with or without pMAC. However, a disk diffusion assay conducted by exposing wild-type, $\Delta$ ohr $R-C, C$ represented gene on chromosome, or $\Delta o h r-C$ single mutants, or $\Delta o h r R-C \Delta o h r-C$ double mutants to tert-butyl hydroperoxide $(t \mathrm{BHP})$ found that the $o h r R-p$-ohr-p genes, $p$ represented genes on pMAC plasmid, may be able to complement the function of their chromosomal counterparts. Interestingly, $\Delta$ ohr-C single mutants generated in A. baumannii ATCC 17978, which does not harbor pMAC, demonstrated delayed exponential growth and loss of viability following exposure to $135 \mu \mathrm{g}$ of $t \mathrm{BHP}$. In a survival assay conducted with Galleria mellonella larvae, these mutants demonstrated almost complete loss of virulence. Via an electrophoretic mobility shift assay (EMSA), we found that OhrR-C was able to bind to the promoter regions of both chromosomal and pMAC ohr-p genes, but with varying affinity. A gain-of-function assay conducted in Escherichia coli showed that OhrR-C was not only capable of suppressing transformed $o h r-C$ genes but may also repress endogenous enzymes. Taken together, our findings suggest that chromosomal ohrR-C-ohr-C genes act as the major system in protecting A. baumannii ATCC 19606 from OHP stresses, but the ohrR-p-ohr-p genes on pMAC can provide a supplementary protective effect, and the interaction between these genes may affect other aspects of bacterial viability, such as growth and virulence.
\end{abstract}

Keywords: Acinetobacter baumannii; Ohr; OhrR; organic hydroperoxide; antibiotic resistance; bacterial viability; bacterial virulence

\section{Introduction}

Bacteria are often exposed to reactive oxygen species (ROS) and other organic hydroperoxides (OHPs) produced by host phagocytic cells [1] as part of the immune response $[2,3]$. OHPs produced by free radical-catalyzed oxidation of polyunsaturated fatty acids (PUFAs) from the host cell [2] are highly toxic molecules that can generate organic free radicals and induce oxidative injury to bacterial cell components. Bacteria have therefore evolved several strategies to protect themselves against oxidative stress. One such strategy is to produce enzymes that can directly detoxify OHPs by transforming them into unreactive alcohols. Ohr (organic hydroperoxide resistance protein) is a thiol peroxidase that is central to the bacterial response against OHPs $[4,5]$, and it acts to neutralize OHPs via a redox-active disulfide bond formed by two conserved cysteines at the catalytic site [6]. Two homologs of Ohr, respectively termed OhrA and OhrB, have been identified in Bacillus subtilis [7]. 
The expression of Ohr enzymes is suppressed by OhrR (organic hydroperoxide resistance regulator) [8]. OhrR belongs to the MarR superfamily of transcription factors and is found in both Gram-negative and Gram-positive bacteria [9]. The oxidation of a highlyconserved cysteine in the N-terminus of OhrR upon exposure to OHPs disrupts its DNA binding activity [10], leading to the derepression of ohr gene. In B. subtilis, the oxidation of the sole cysteine residue in OhrR allows the regulator to retain its DNA-binding activity, and the derivative from an additional oxidation is required for derepression [11,12]. In Burkholderia thailandensis, OhrR oxidation results in the formation of a reversible disulfide bond between conserved cysteines in the N-terminus and C-terminus of separate monomers resulting for attenuation of DNA binding in vitro [13].

Acinetobacter baumannii, a type of gammaproteobacteria of the Moraxellaceae family, is widely found in soil, water, animals, and food items, and has gained increasing attention in recent years due to its role in nosocomial infections $[14,15]$. A. baumannii can induce a vast range of serious infections, including pneumonia, bloodstream infections, urinary tract infections, wound and burn infections, and secondary meningitis [15-18]. According to genomic data from the National Center for Biotechnology Information (NCBI), as of January 2021, genome assemblies for at least 4914 strains of $A$. baumannii have been deposited, and high genomic diversity between strains has been observed. The most studied A. baumannii strain, ATCC 17978, was isolated from a four-month-old infant with fetal meningitis, while the ATCC 19606 strain used in this study was isolated from urine [19]. Plasmid availability is one of the most important distinctions between these two strains, as A. baumannii ATCC 19606 harbors pMAC, a 9540-base pair (bp) plasmid that contains 11 annotated open reading frames (ORFs) [20]. ORF8 and ORF9 have been respectively annotated as ohrA and $o h r R$, and this has been confirmed through functional analysis in Escherichia coli [20].

In this study, we identified the presence of another ohrR-C-ohr-C gene cluster in the chromosomal DNA of A. baumannii ATCC 19606 through in silico analysis, and subsequently investigated the function and significance of this newly-discovered set of ohr-c genes. Our results show that chromosomal ohrR-C-ohr-C may play a greater role in resistance to OHPs, and this may have implications for the study of ohr genes in other bacterial species, as well as the development of novel antibacterial therapies against $A$. baumannii infections.

\section{Material and Methods}

\subsection{Bacterial Strains and Culturing Conditions}

A. baumannii ATCC 19606 and E. coli strains were grown in LB medium [21] at $37^{\circ} \mathrm{C}$ with shaking. All of the strains were listed in Table 1. LB medium with $1.5 \%$ agar was prepared for solid cultures. Antibiotics were used at different concentrations according to the cultured strains.

The growth curve of each strain was determined according to culture turbidity, using optical density measurements at $600 \mathrm{~nm}\left(\mathrm{OD}_{600}\right)$. Viable bacteria counts for each strain were determined using the drop plate method, as previously described [22]. At each time point, $5 \mu \mathrm{L}$ of 10 -fold serially diluted bacteria was dropped on LB agar plates containing ampicillin to establish viable bacteria counts. Bacterial growth curves were determined every three hours for the first $12 \mathrm{~h}$, after which bacterial viability was assessed every $12 \mathrm{~h}$, until $48 \mathrm{~h}$ had elapsed from the initial drop.

\subsection{Markerless Mutant Generation}

Both $o h r-C$ and $o h r R-C$ mutants were generated by markerless gene deletion. The upstream and downstream DNA fragments of the respective genes were amplified by PCR, using the primers listed in Table 2, and were cloned into the BamHI and HindIII sites of plasmid pK18mobsecB (Table 1) [23] using the Gibson assembly cloning kit (New England Biolabs; Ipswich, MA, USA). The resulting plasmid was transformed into E. coli S17-1 $\lambda$ pir to produce a donor for conjugation with $A$. baumannii. This plasmid DNA was maintained in the chromosomal region near ohr-C through the first homologous recombination event, 
and it was selected using the kanamycin resistance gene. Excision of the resulting plasmid DNA by the second crossover event was facilitated by selection on medium containing $10-20 \%$ sucrose but without kanamycin. The deletion mutant was obtained without any markers and was subsequently confirmed by PCR analysis.

Table 1. Plasmids and bacterial strains used in this study.

\begin{tabular}{|c|c|c|c|}
\hline Plasmid & Description & $\begin{array}{l}\text { Antibiotic Resistance } \\
\qquad(\mu \mathrm{g} / \mathrm{mL})\end{array}$ & Reference/Source \\
\hline pK18mobsecB & $\begin{array}{l}\text { Suicide vector for homologous } \\
\text { recombination }\end{array}$ & Km50 & {$[23]$} \\
\hline pK18dohrR & $\begin{array}{l}\text { pK18mobsecB contains the upstream and } \\
\text { downstream regions of } o h r R-C\end{array}$ & $\mathrm{Km} 50$ & This study \\
\hline pK18dohr & $\begin{array}{l}\text { pK18mobsecB contains the upstream and } \\
\text { downstream regions of } o h r-C\end{array}$ & Km50 & This study \\
\hline pK18dohrRohr & $\begin{array}{l}\text { pK18mobsecB contains the upstream and } \\
\text { downstream regions of ohrR-C-ohr-C }\end{array}$ & Km50 & This study \\
\hline pQE80L & $\begin{array}{l}\text { Expression vector with colE1 origin for } \\
\text { His-tag fusion protein purification }\end{array}$ & Amp50 & Qiagen \\
\hline pOhrR-C & $\begin{array}{c}\text { ohrR-C gene with N-terminal-fused His-tag } \\
\text { in pQE80L }\end{array}$ & Amp50 & This study \\
\hline pOhrR-C-P ${ }_{\text {ohr }}-\mathrm{ohr}-\mathrm{C}$ & $\begin{array}{l}\text { ohr-C and ohrR-C gene promoter was } \\
\text { cloned downstream of pOhrR-C }\end{array}$ & Amp50 & This study \\
\hline Strain & \multicolumn{2}{|l|}{ Description } & Reference/Source \\
\hline E. coli $\mathrm{DH} 5 \alpha$ & \multirow{3}{*}{\multicolumn{2}{|c|}{$\begin{array}{c}\mathrm{F}^{-}, \text {supE44, hsdR17, recA1, gyrA96, endA1, thi-1, relA1, deoR, } \lambda^{-} \\
\text {thi-, thr , leu, tonA , lacY, supE, recA::RP4-2-Tc::Mu, Smr, lpir } \\
\text { Primary strain used in this study }\end{array}$}} & ATCC 53868 \\
\hline E. coli $\mathrm{S} 17-1 \lambda$ pir & & & [23] \\
\hline Acinetobacter baumannii ATCC 19606 & & & [19] \\
\hline $\begin{array}{l}\text { Acinetobacter baumannii } \\
\text { ATCC } 17978\end{array}$ & \multicolumn{2}{|c|}{ Most studied strain to date } & {$[14]$} \\
\hline$\Delta o h r R$ & \multicolumn{2}{|c|}{ Marker-less $o h r R-c$ deletion mutant } & This study \\
\hline$\Delta o h r$ & \multicolumn{2}{|c|}{ Marker-less $o h r-c$ deletion mutant } & This study \\
\hline$\Delta o h r R o h r$ & \multicolumn{2}{|c|}{ Marker-less $o h r R-c-o h r-c$ deletion mutant } & This study \\
\hline
\end{tabular}

Amp: ampicillin; Km: kanamycin.

\subsection{Minimum Inhibition Concentration}

The resistance of each strain to antibiotics was assessed by liquid minimum inhibition assay. Specifically, each antibiotic was inoculated into 96-well microtiter plates with 2-fold serial dilution. Each strain was cultured in $3 \mathrm{~mL}$ of LB medium at $37^{\circ} \mathrm{C}$ overnight. Diluted overnight cultures with an $\mathrm{OD}_{600}$ of 0.1 were then inoculated into 96-well microtiter plates. Optical density was determined after overnight culture. The MIC was defined as the lowest concentration of antibiotics that inhibit bacterial proliferation [24].

\subsection{Disk Diffusion Assay}

The resistance of each strain to organic hydroperoxide was evaluated by disk diffusion assy. In brief, each strain was cultured in $3 \mathrm{~mL}$ of LB medium at $37^{\circ} \mathrm{C}$ overnight. Diluted overnight cultures with an $\mathrm{OD}_{600}$ of 0.1 were then densely inoculated onto LB agar plates using a cotton swab, in order to ensure the confluent growth of each strain. Whatman filter paper discs imbued with $5 \mu \mathrm{L}$ of $300 \mu \mathrm{M} t \mathrm{BHP}$ were aseptically applied to the surface of the agar plate, and the zones of growth inhibition were measured after incubation for $16 \mathrm{~h}$ at $37^{\circ} \mathrm{C}$.

\subsection{RNA Extraction and $q R T-P C R$}

Each strain was cultured in LB medium with agitation at $37^{\circ} \mathrm{C}$ overnight. Bacteria were sub-cultured in a fresh $50 \mathrm{~mL}$ medium for three hours. Samples were collected for the non-treatment group and mixed with 0.1 volume of fixing solution ( $5 \%$ acid phenol, $95 \%$ 
ethanol). After centrifugation by $17,000 \times g$ at $4{ }^{\circ} \mathrm{C}$, the supernatant was discarded, and the remaining cell pellets were stored at $-80^{\circ} \mathrm{C}$ for RNA extraction.

Table 2. Gene-specific primers used in this study.

\begin{tabular}{|c|c|c|}
\hline Name & Sequences $\left(5^{\prime}-3^{\prime}\right)$ & Function \\
\hline ohrR MU F & GCTGTGGGTGGATATCAGGA & Construction of $\Delta o h r R$ \\
\hline ohrR MU R & CAGTGACTCGTCTTAAAGAT & Construction of $\Delta o h r R$ \\
\hline pk18_ohrup_F & $\begin{array}{l}\text { CGAGCTCGGTACCCGGGCGG } \\
\text { GACAACGAATAATTTTG }\end{array}$ & Construction of $\Delta o h r$ \\
\hline ohrup-ohrdo-R & $\begin{array}{c}\text { CCAATGAAGCAAGTGAAGCA } \\
\text { TTATTTAGCTATATTTGTACGGAGC }\end{array}$ & Construction of $\Delta o h r$ \\
\hline ohrup-ohrdo-F & $\begin{array}{c}\text { GCTCCGTACAAATATAGCTA } \\
\text { AATAATGCTTCACTTGCTTCATTGG }\end{array}$ & Construction of $\Delta o h r$ \\
\hline ohrdo-pK18-R & $\begin{array}{c}\text { AACGACGGCCAGTGCCATTT } \\
\text { ACGTCTTGCTGGTCGTG }\end{array}$ & Construction of $\Delta o h r$ \\
\hline pk18_ohrRup_F & $\begin{array}{l}\text { CGAGCTCGGTACCCGGGCAT } \\
\text { CTACCCCTTTTGGCAAT }\end{array}$ & Construction of $\Delta o h r R \Delta o h r$ \\
\hline ohrRup- ohrdo-R & $\begin{array}{l}\text { CCAATGAAGCAAGTGAAGCA } \\
\text { CCTCAGAAAACTAATGGGTGCT }\end{array}$ & Construction of $\Delta o h r R \Delta o h r$ \\
\hline ohr Rup- ohr do-F & $\begin{array}{l}\text { AGCACCCATTAGTTTTCTGA } \\
\text { GGTGCTTCACTTGCTTCATTGG }\end{array}$ & Construction of $\Delta o h r R \Delta o h r$ \\
\hline nptII-F & ATGATTGAACAAGATGGATTGC & Amplification of kanamycin resistant gene \\
\hline nptII-R & TCAGAAGAACTCGTCAAGAAG & Amplification of kanamycin resistant gene \\
\hline gyrase-PF & AACCTATATTTGCTAGGGAG & Amplification of gyraeB promoter region \\
\hline gyrase-PR & TACTAGAGGAATCATAAGCC & Amplification of gyraeB promoter region \\
\hline ohr-1 up & $\begin{array}{c}\text { ACCAATTTTTTTACAAAATT } \\
\text { GACTTGTTAAAATAATTAAGTCGTG }\end{array}$ & Amplification of $o h r-c$ promoter region \\
\hline ohr-1 bo & $\begin{array}{c}\text { CACGACTTAATTATTTTAAC } \\
\text { AAGTCAATTTTGTAAAAAAATTGGT }\end{array}$ & Amplification of $o h r-c$ promoter region \\
\hline$o h r-2$ up & $\begin{array}{l}\text { TACGATATATTTGCATTCAA } \\
\text { TTTAATTTAGGAATAAAAAG }\end{array}$ & Amplification of $o h r$ promoter region \\
\hline ohr-2 bo & $\begin{array}{l}\text { CTTTTTATTCCTAAATTAAA } \\
\text { TTGAATGCAAATATATCGTA }\end{array}$ & Amplification of $o h r-c$ promoter region \\
\hline Ohr-3_PF & TTGACTTGTTAAAATAATTAAGTCG & Amplification of $o h r-c$ promoter region \\
\hline$o h r \_\bar{P} F$ & ACCAATTTTTTTACAAAATT & Amplification of $o h r-c$ promoter region \\
\hline$o h r \_P R$ & СТTТTТАТТССТАААТТААА & Amplification of $o h r-C$ promoter region \\
\hline pMAC_ohr_PF & GGCCGATATAAGCTCTATTT & Amplification of $o h r-p$ promoter region \\
\hline pMAC_ohr_PR & TGTATATTACCTTGCTTAAT & Amplification of $o h r-p$ promoter region \\
\hline ohrR_kpnI_flag-R & $\begin{array}{c}\text { GGGGTACCCTTGTCGTCATCGTCTTTG } \\
\text { TAGTCTTCAGTCACAATATTAAACG }\end{array}$ & Construction of pOhrR-C- $\mathrm{P}_{\mathrm{ohr}}-\mathrm{ohr}-\mathrm{C}$ \\
\hline$o h r R F$ & CGGGATCCATGGACCAAGACTGTCAAA A & Specific primer of chromosomal $\mathrm{ohr} R-\mathrm{C}$ \\
\hline$o h r R$ R & GGGGTACCTTATTTAGCTATATTTGTAC & Specific primer of chromosomal $\mathrm{hhr}-\mathrm{C}$ \\
\hline ohrR qF & TGGACCAAGACTGTCAAAATC & qRT-PCR primer for $o h r R-C$ \\
\hline ohrR qR & TCCCACAACACCAACATCAC & qRT-PCR primer for $o h r R-C$ \\
\hline ohr qF-2 & AAGCAACAGGTGGCCGTGAT & qRT-PCR and specific primer of chromosomal ohr-C \\
\hline ohr qR-2 & ACCGACTTCACCTTCAACATACGC & qRT-PCR and specific primer of chromosomal ohr-C \\
\hline ABpMAC_ohrR_F & TGTCCAAGAATCAGCTTTGCT & qRT-PCR and specific primer of $o h r R-p$ \\
\hline ABpMAC_ohrR_R & TTTGTCCAAGATCACCCACA & qRT-PCR and specific primer of $o h r R-p$ \\
\hline ABpMAC_ohr_F & AAAGGTGATGCAACGAATCC & qRT-PCR and specific primer of $o h r-p$ \\
\hline ABpMAC_ohr_R & GTCAAGGCAAATCCACCATT & qRT-PCR and specific primer of $o h r-p$ \\
\hline$g y r B-F$ & GGCGGTTTATCTGAGTTTGT & qRT-PCR primer for gyrase gene of A. baumannii \\
\hline gyrB-R & TTTGTGGAATGTTGTTTGTG & qRT-PCR primer for gyrase gene of $A$. baumannii \\
\hline
\end{tabular}

Cell pellets were thawed on ice and resuspended in $1 \mathrm{~mL}$ of NucleoZOL (MACHEREYNAGEL; Düren, Germany), mixed thoroughly with $400 \mu \mathrm{L}$ of diethyl pyrocarbonate (DEPC)-treated $\mathrm{H}_{2} \mathrm{O}$, and then incubated at room temperature for $15 \mathrm{~min}$. The supernatant was recovered after centrifugation at $17,000 \times g$ at $4{ }^{\circ} \mathrm{C}$ for $20 \mathrm{~min}$, then fully mixed with $5 \mu \mathrm{L}$ of $100 \%$-bromoanisole and incubated at room temperature for $10 \mathrm{~min}$. Excess protein was removed by centrifugation at $17,000 \times g$ at $4{ }^{\circ} \mathrm{C}$ for $20 \mathrm{~min}$. The RNA 
suspension was subsequently mixed with an equal volume of isopropanol for $15 \mathrm{~min}$ for RNA precipitation. The RNA pellet was washed twice with ice-cold $75 \%$ ethanol and resuspended in $30 \mu \mathrm{L}$ of DEPC-treated $\mathrm{H}_{2} \mathrm{O}$ for the following analysis.

A total of $2 \mu \mathrm{g}$ of RNA was subsequently used to prepare cDNA after a Nanodrop spectrophotometer (NanoDrop 2000C, Thermo Fisher Scientific; Waltham, MA, USA) analysis was conducted to determine RNA concentrations. The qRT-PCR mixture contained $10 \times$ reaction buffer, $200 \mathrm{U}$ of MMLV high performance reverse transcriptase (Epicentre; Madison, WI, USA), $100 \mathrm{mM}$ of dithiothreitol (DTT), $2.5 \mathrm{mM}$ dNTP, and $1 \mathrm{nM}$ of hexamer. The reaction was conducted in a LightCycler ${ }^{\circledR} 480$ (Roche; Basel, Switzerland). Genespecific primers used to determine the presence and expression levels of the ohr-C, ohrR-C, $o h r-p$, and ohrR-p genes are listed in Table 2. The gyrase gene served as an internal control, and was amplified by PCR using the specific primers, gyrF and gyrR (Table 2) [25].

\subsection{OhrR Overexpression and Purification}

The PCR product of the ohrR-C gene was amplified using ohrR-c-F and ohrR-c-R primers, and cloned into the BamHI and KpnI sites of plasmid pQE80L (Qiagen, Hilden, Germany) to generate pOhrR-C. To express OhrR-C protein, E. coli DH5 $\alpha$ (pOhrR-C) was expanded at $37^{\circ} \mathrm{C}$ by inoculating a $0.5-\mathrm{mL}$ overnight culture into $50 \mathrm{~mL}$ of LB medium containing ampicillin. Incubation was continued at $37^{\circ} \mathrm{C}$ until the culture reached an $\mathrm{OD}_{600}$ of 0.6. Protein expression was induced by adding IPTG to achieve a final concentration of $1 \mathrm{mM}$. After incubation overnight at $37^{\circ} \mathrm{C}$, the cells were harvested by centrifugation at $4000 \times g$ for $15 \mathrm{~min}$. The cells were then stored at $-80^{\circ} \mathrm{C}$ until use.

OhrR-C protein purification was performed by a method described elsewhere [26]. Frozen cells overexpressing OhrR-C were suspended in $30 \mathrm{~mL}$ of $1 \times$ binding buffer containing $5 \mathrm{mM}$ imidazole, $0.5 \mathrm{mM} \mathrm{NaCl}$, and $20 \mathrm{mM}$ Tris- $\mathrm{HCl}$ (pH 8.0) and subjected to 3 cycles of freezing and thawing at $-80^{\circ} \mathrm{C}$ and room temperature, respectively. The thawed cells were disrupted by high pressure at $4{ }^{\circ} \mathrm{C}$ using a low-temperature cell disruptor, JNBIO JN-O2C (Guangzhou, China). The cell extract was separated from the cell debris by centrifugation at $17,000 \times g$ for $30 \mathrm{~min}$ at $4{ }^{\circ} \mathrm{C}$ (Avanti J-25 Centrifuge, JA25.5 rotor, Beckman Coulter; Brea, CA, USA). The OhrR-C containing cell extract was then purified by Ni-affinity chromatography (Novagen; Madison, WI, USA). Purified fractions were analyzed via $15 \%$ sodium dodecyl sulfate polyacrylamide gel electrophoresis (SDS-PAGE) and stained with Coomassie Brilliant Blue G-250.

\subsection{EMSA}

The DNA fragment of the ohr-C promoter and ohr-p promoter were amplified by PCR, using gene-specific primers (Table 2). EMSA was performed as previously described, with some modifications [26]. The reaction mixtures for the binding assays contained different concentrations of OhrR-C protein. The binding reactions were performed in binding reaction buffer ( $20 \mathrm{mM}$ Tris- $\mathrm{HCl}(\mathrm{pH} 7.5), 100 \mathrm{mM} \mathrm{MgCl} 2,150 \mathrm{mM} \mathrm{KCl}, 50 \mathrm{mM}$ EDTA, $12.5 \%$ glycerol) supplemented with $250 \mu \mathrm{M}$ DTT, $830 \mathrm{ng} / \mathrm{mL}$ poly $(\mathrm{dI}-\mathrm{dC})$ and $250 \mathrm{ng} / \mathrm{mL}$ bovine serum albumin (BSA). The reaction mixtures were incubated for $30 \mathrm{~min}$ at room temperature before adding $50 \mathrm{nM}$ of DNA fragments. Samples were incubated for another $30 \mathrm{~min}$, they were mixed with an equal volume of sample buffer $(62 \mathrm{mM}$ Tris- $\mathrm{HCl}, 0.01 \%$ bromophenol blue, and 10\% glycerol) and loaded onto $8 \%$ non-denaturing polyacrylamide gels containing $0.5 \times$ Tris-borate-EDTA buffer. Electrophoresis was performed at $100 \mathrm{~V}$ for $1-1.5 \mathrm{~h}$ at $4{ }^{\circ} \mathrm{C}$. Images were captured after the gels were stained with SYBR Gold Nucleic Acid Gel Stain (Thermo Fisher Scientific; Waltham, MA, USA) for 20 min at room temperature, and imaged using the Ultra Slim LED Illuminator (MAESTROGEN; Hsinchu City, Taiwan). A DNA fragment of the gyrase gene promoter from A. baumannii was amplified by PCR, using the specific primers $g y r-p \mathrm{~F}$ and $g y r-p \mathrm{R}$ (Table 2), and was used as a negative (non-specific) control. 


\subsection{G. Mellonella Experiments}

A virulence comparison was performed for A. baumannii ATCC 19606, ATCC 17978 and the ohr-C or ohrR-C mutants of each strain. All the procedures were performed as previously described, with minor modifications [27]. Overnight cultures of each strain were washed twice with PBS $\left(0.137 \mathrm{M} \mathrm{NaCl}, 2.7 \mathrm{mM} \mathrm{KCl}, 10 \mathrm{mM} \mathrm{Na}_{2} \mathrm{HPO}_{4}, 1.8 \mathrm{mM} \mathrm{KH}_{2} \mathrm{PO}_{4}\right)$, then diluted in PBS. Ten G. mellonella larvae were selected for the same total weight and were kept in Petri dishes without food prior to infection. Each larva was infected with $5 \times 10^{6}$ colony-forming units (CFU) of each strain. Bacteria in 10-mL aliquots were injected into the hemocoel of each larva via the last left proleg by a Hamilton syringe. Infected larvae were incubated at $37^{\circ} \mathrm{C}$ and scored for survival (alive/dead) every $24 \mathrm{~h}$. Larvae were also scored for melanization over $96 \mathrm{~h}$, according to a previously described scoring method [28].

\section{Results}

3.1. Identification of Two Paralogous ohr-ohrR Genes in A. baumannii ATCC 19606

Previous research showed that the pMAC plasmid in A. baumannii ATCC 19606 contains 11 ORFs, with ORF8 and ORF9 respectively annotated as putative OhrA and OhrR enzymes that can contribute to tert-butyl hydroperoxide ( $t \mathrm{BHP}$ ) resistance [20]. Using an in silico analysis, we proceeded to identify another set of putative Ohr-C (DJ41_1043) and OhrR-C (DJ41_1042) proteins on the chromosomal DNA of A. baumannii ATCC 19606, and these shared $44.4 \%$ and $41.3 \%$ identity with ORF8 and ORF9 on pMAC. Interestingly, the chromosomal ohrR-C gene is located upstream of the chromosomal ohr-C gene, and the genetic architecture suggests that each gene possesses its own promoter regions, and can be transcribed independently in the same direction (Figure 1); however, on pMAC, ORF8 is located upstream from ORF9, and considering that the start codon of ORF9 is located only $7 \mathrm{bp}$ downstream of the stop codon of ORF8, it is possible that both genes may be transcribed on the same mRNA (Figure 1).
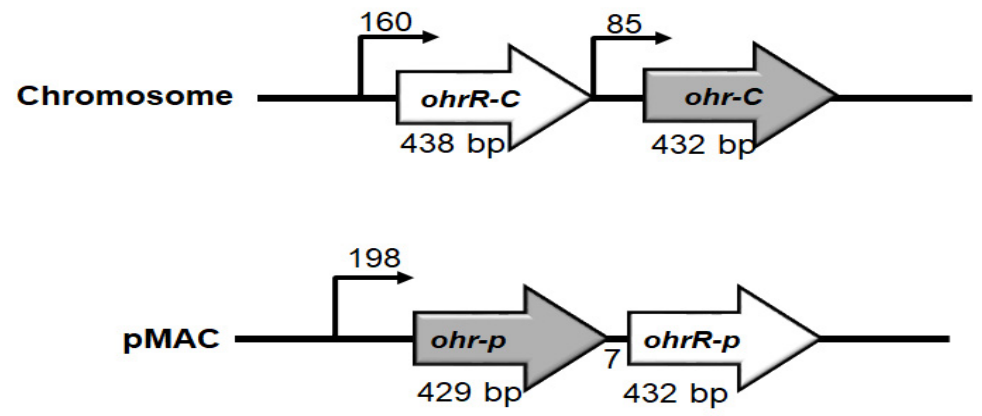

Figure 1. Genetic organization of $o h r-o h r R$ genes on chromosomal DNA and pMAC. Numbers above bent arrows indicate the distance in base pairs between two genes.

We proceeded to label ORF8 as Ohr-p and ORF9 as OhrR-p, in order to distinguish them from their chromosomal counterparts. We found that Ohr-p shared $44.4 \%$ amino acid similarity with chromosomal $\mathrm{Ohr}(\mathrm{Ohr}-\mathrm{C})$ and $41.5 \%$ similarity with OhrA of Xanthomonas campestris pv. phaseoli. Ohr-C was found to share $37.1 \%$ similarity with Ohr of E. coli (OhrEc), and 56.3\% similarity with OhrA of X. campestris (Ohr-Xc) (Figure S1A). Chromosomal OhrR (OhrR-C) shared 41.3\% amino acid similarity with OhrR-p, and 51.5\%, 48.6\%, and $45.9 \%$ similarity with OhrR of X. campestris (OhrR-Xc), Pseudomonas aeruginosa (OhrR-Pa), and B. subtilis (OhrR-Bs), respectively (Figure S1B). Secondary structure analysis of OhrR-C revealed six $\alpha$-helices and two $\beta$-sheets, consistent with the typical structure of a MarR protein (Figure S1B).

\subsection{Role of ohr-p and ohrR-p in tBHP Resistance Is Limited}

Several methods have been applied by our lab (data not shown) and others [20] to evaluate the role of pMAC in organic peroxide resistance by plasmid curing, but these 
efforts were not successful since we can find pMAC in bacteria after curing process. To screen for the presence of chromosomal ohrR-C-ohr-C and ohr-p-ohrR-p genes on pMAC in different Acinetobacter strains for which genomic sequences are not available but identified by $16 \mathrm{~S}$ rRNA gene amplification and sequences analysis. Gene-specific primers were designed for gene amplification (Table 2). Subsequent PCR results revealed that most Acinetobacter spp. had chromosomal ohrR-C-ohr-C genes, except $A$. soli (Figure 2A, lane 7). However, ohr-p-ohrR-p genes on pMAC were only found in A. baumannii ATCC 19606 and A. baumannii ATCC 15308 (Figure 2A, lanes 8, 9, 10). Growth conditions in the presence of $135 \mu \mathrm{g}$ of $t \mathrm{BHP}$ were assessed for each of these strains, using the disk diffusion assay, but no significant difference in $t \mathrm{BHP}$ resistance was observed between strains with or without the pMAC plasmid (Figure 2B). Different concentrations of $t \mathrm{BHP}$ and cumene hydroperoxide were also tested, but the results were similar to those observed with $135 \mu \mathrm{g}$ of $t \mathrm{BHP}$ (data not shown). This suggests that the ohr-p-ohrR-p genes on pMAC have a limited role in $t \mathrm{BHP}$ resistance, and we therefore focused on elucidating the functional role of chromosomal ohrR-C-ohr-C genes in subsequent experiments.

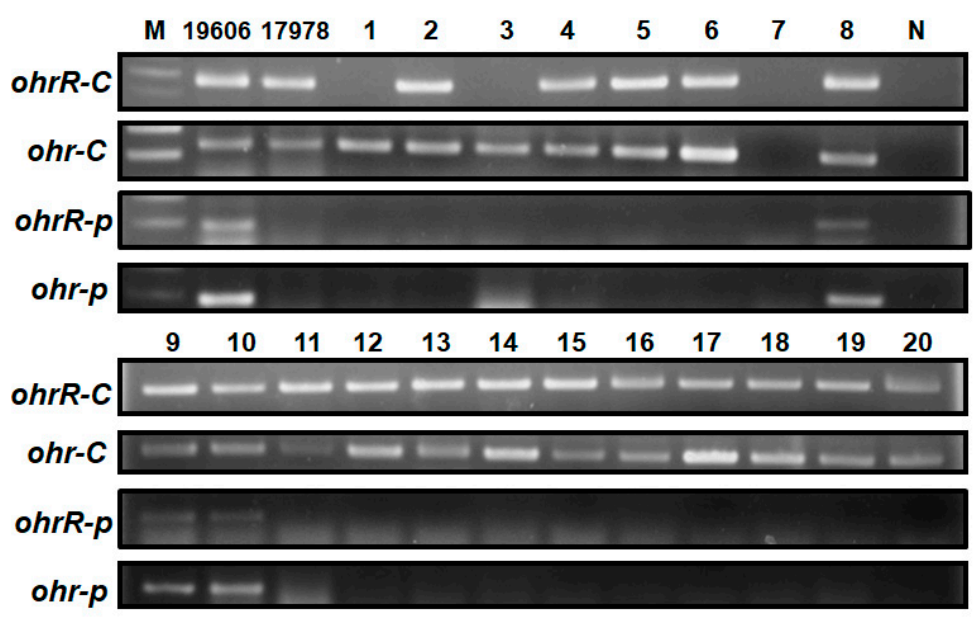

(A)

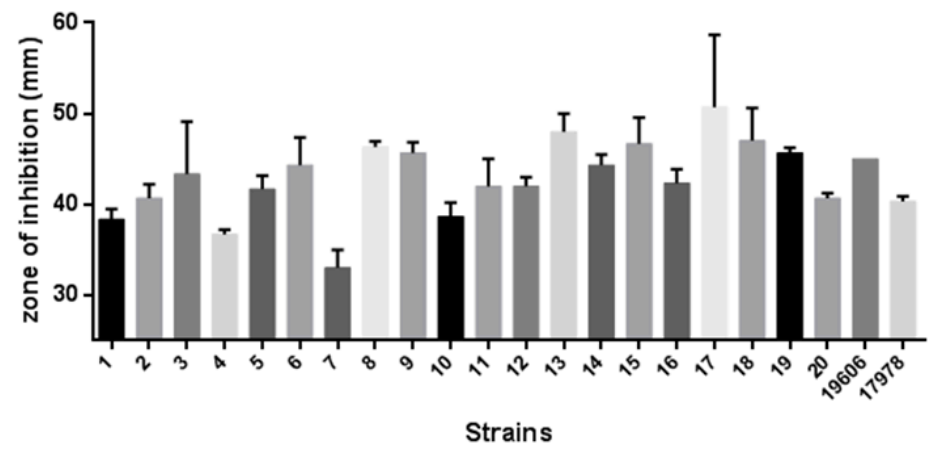

(B)

Figure 2. Presence of $o h r R-o h r$ genes and $t$ BHP resistance of 20 Acinetobacter isolates. (A) PCR products amplified by primers specific to chromosomal or pMAC ohrR-ohr genes. (B) Inhibition zones for each isolate following treatment with $135 \mu \mathrm{g}$ of $t \mathrm{BHP}$ in a disk diffusion assay. Numbers 1-20 indicate the strain numbers of Acinetobacter isolates. $\mathrm{M}$ is a molecular weight marker. $\mathrm{N}$ is a negative control using $\mathrm{ddH}_{2} \mathrm{O}$ as a template. 19606 and 17978 indicate A. baumannii ATCC 19606 and ATCC 17978, respectively. These data were obtained from three independent experiments.

\subsection{Chromosomal ohr-C Plays an Important Role in Bacterial Proliferation}

To understand the importance of chromosomal ohrR-C-ohr-C genes for A. baumannii ATCC 19606, we constructed single and double $o h r R-C$ and ohr-C mutants by markerless allelic exchange. Bacteria used in these experiments were all cultured in lysogeny broth 
(LB), and the optical density and viable count of cultures was determined every three hours over a 24-h period, in order to obtain growth curves for each strain. Results revealed no significant difference in growth curves for wild-type and mutant $A$. baumannii ATCC 19606 (Figure 3A). In addition, ohrR-C and ohr-C single mutants were also generated in A. baumannii ATCC 17978, and growth curves showed that the ohr-C mutant underwent a delay in entering the exponential growth phase during the first $12 \mathrm{~h}$, but eventually reached comparable levels of growth with wild-type after entering the stationary phase (Figure 3B). These results suggest an important role for chromosomal ohr-C in overcoming organic peroxide stress during the exponential growth phase for A. baumannii ATCC 17978. However, we did not observe similar results with ohr-C single and ohrR-C-ohr-C double mutants of A. baumannii ATCC 19606 cultured in LB medium for $24 \mathrm{~h}$, implying that the ohr-p-ohrR-p genes on pMAC may act to reduce organic peroxide stress (Figure 3A).

Antibiotic testing was used to determine the minimum inhibition concentration of different strains, and the results showed that there were no significant differences between A. baumannii ATCC 19606 strains. However, loss of ohrR-C increased kanamycin resistance in A. baumannii ATCC 17978, while the ohr-C mutant became more susceptible to antibiotics tested (Figure 3C). This suggests that the ohr-p-ohrR-p genes on pMAC may enhance resistance by mitigating organic peroxide stress generated during antibiotic treatment.

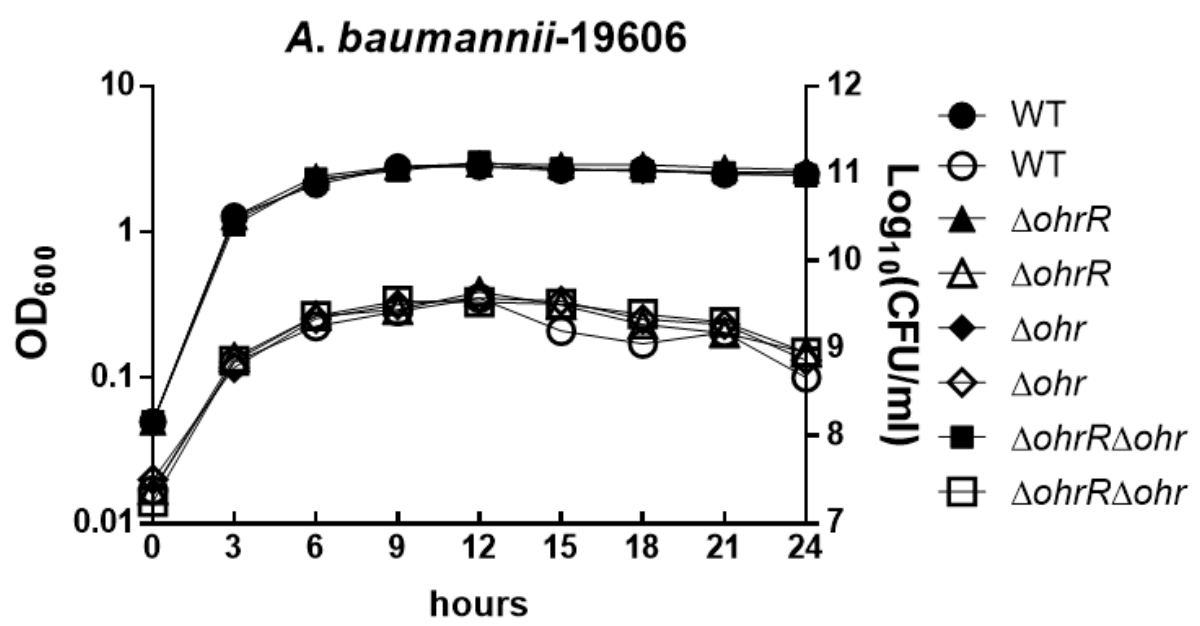

(A)

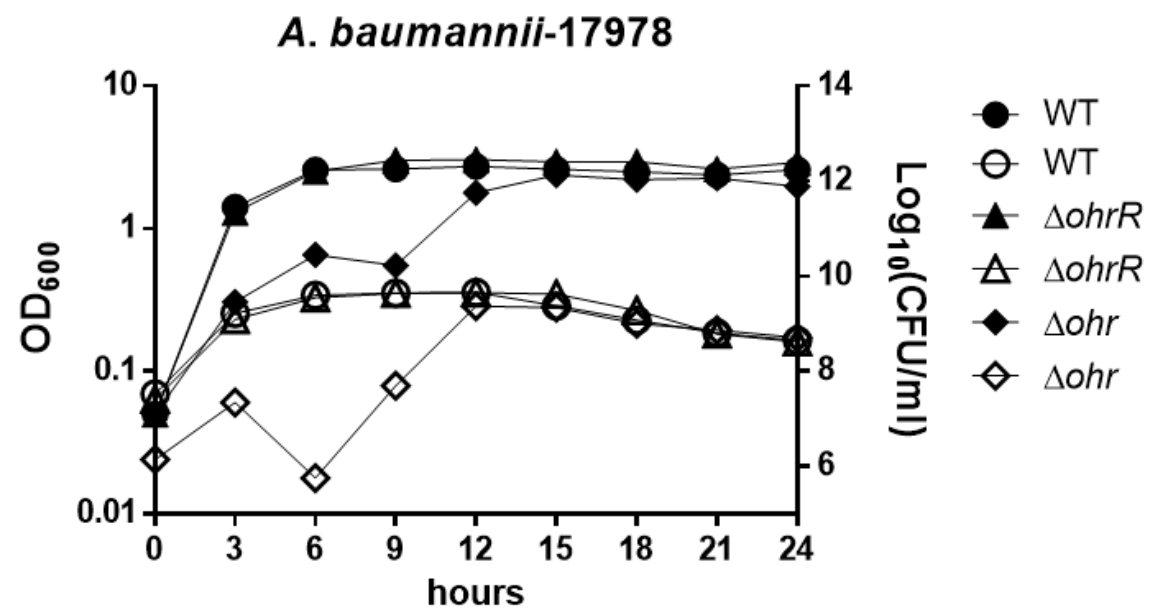

(B)

Figure 3. Cont. 


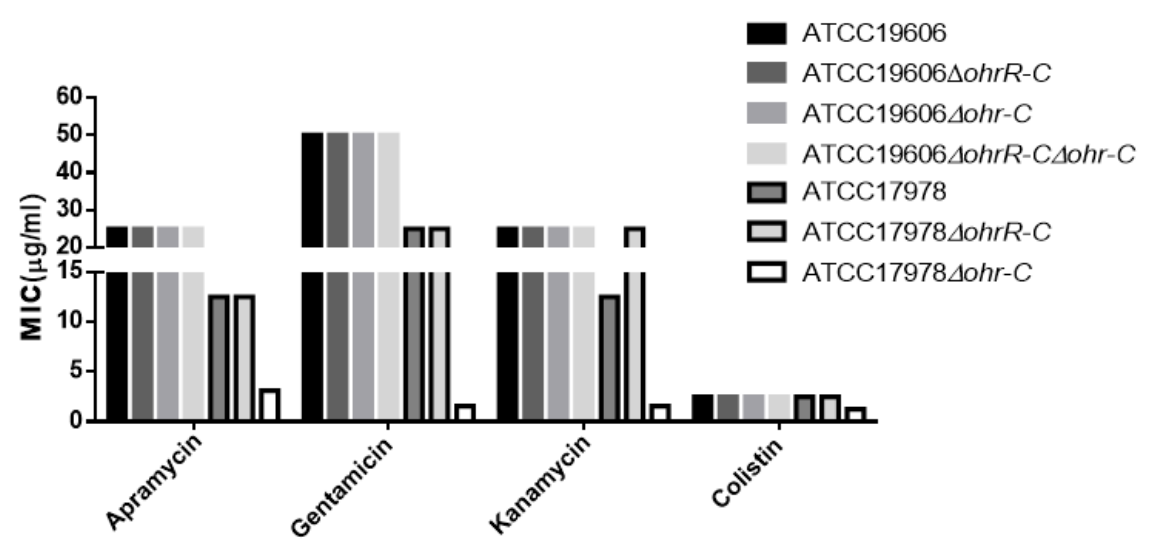

(C)

Figure 3. Growth curve of different $A$. baumannii strains in LB medium and minimum inhibition concentration (MIC) of different strains treated by different antibiotics. Growth curve of (A) $A$. baumannii ATCC 19606 and (B) A. baumannii ATCC 17978 wild-type and mutant strains. The $Y$-axis at left represents $\mathrm{OD}_{600}$, while the $Y$-axis at right represents viable cell count. Filled symbols represent the optical density and empty symbols indicate the viable cell counts of each strain. These data were obtained from three independent experiments. (C) MIC of different strains.

\subsection{Gene Expression of Chromosomal ohr-C Can Be Induced by tBHP}

To assess gene expression levels for chromosomal ohrR-C-ohr-C and pMAC ohr-p-ohrR$p$ genes, quantitative reverse transcription PCR (qRT-PCR) was conducted to analyze gene expression in bacteria with or without $t \mathrm{BHP}$ treatment. A. baumannii wild type, ohr $R-C$, ohr- $C$ single and double mutants were sub-cultured in $\mathrm{LB}$ medium at an initial $\mathrm{OD}_{600}$ of 0.05 for $3 \mathrm{~h}$, and then treated with $200 \mu \mathrm{M}$ of $t \mathrm{BHP}$ for $20 \mathrm{~min}$ prior to acid phenol fixation. Samples were stored at $-80^{\circ} \mathrm{C}$ if RNA extraction was not performed immediately. Gene-specific primers (Table 2) were used to perform qRT-PCR, and the results showed that in the presence of $t \mathrm{BHP}$, ohr-C and ohr- $p$ expression respectively increased by 1.76 -fold and 4.12-fold over untreated controls (Figure 4A). In $\Delta$ ohrR-C mutants, ohr-C expression increased more than 100-fold over wild-type. Both ohrR-p and ohr-p did not demonstrate significantly elevated gene expression in all mutants (Figure $4 \mathrm{~B}$ ). In $\triangle$ ohr $R-C$ mutants, $t \mathrm{BHP}$ induced 50-fold higher chromosomal ohr-C expression over wild-type strains, indicating that OhrR-C has a repressive effect on ohr-C expression, but little effect on ohr-p expression (Figure $4 \mathrm{C}$ ). As for the expression of ohr-p-ohrR-p genes on pMAC in the presence of $t \mathrm{BHP}$, neither $o h r-p$ nor $o h r R-p$ gene expression was strongly induced in $o h r-C$ single mutants or ohrR-C-ohr-C double mutants (Figure $4 \mathrm{C}$ ). These results indicate that even with the loss of ohrR-C-ohr-C, the ohr-p genes on pMAC will not be upregulated to overcome the effects of $t$ BHP treatment. To further clarify the role of chromosomal ohrR-C-ohr-C, mutants were generated in a strain without pMAC (A. baumannii ATCC 17978), and qRT-PCR was conducted to assess gene expression with or without $t \mathrm{BHP}$ treatment. The results were similar to those observed for A. baumannii ATCC 19606, in which ohr-C expression was induced by $t$ BHP (Figure 5A) and repressed by OhrR-C (Figure 5B). 


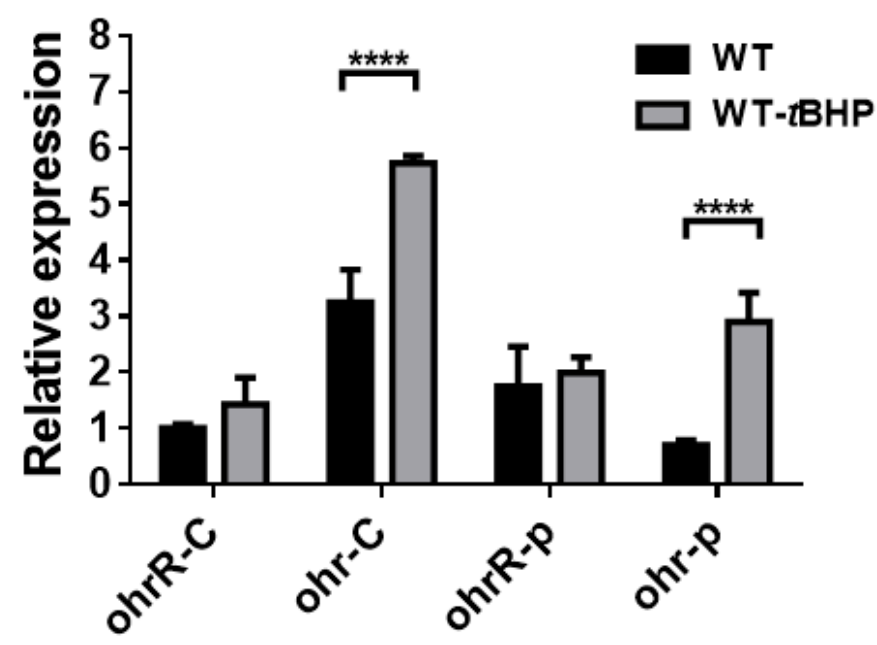

(A)

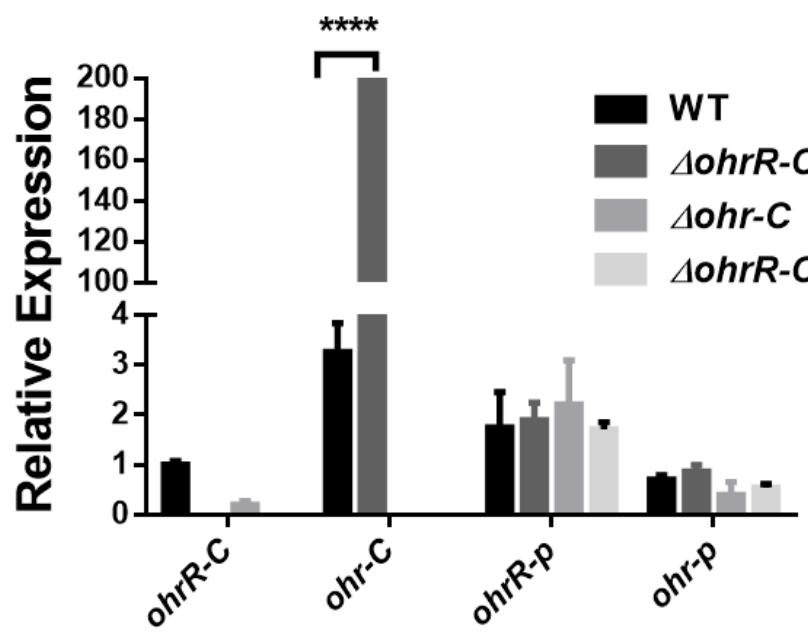

(B)

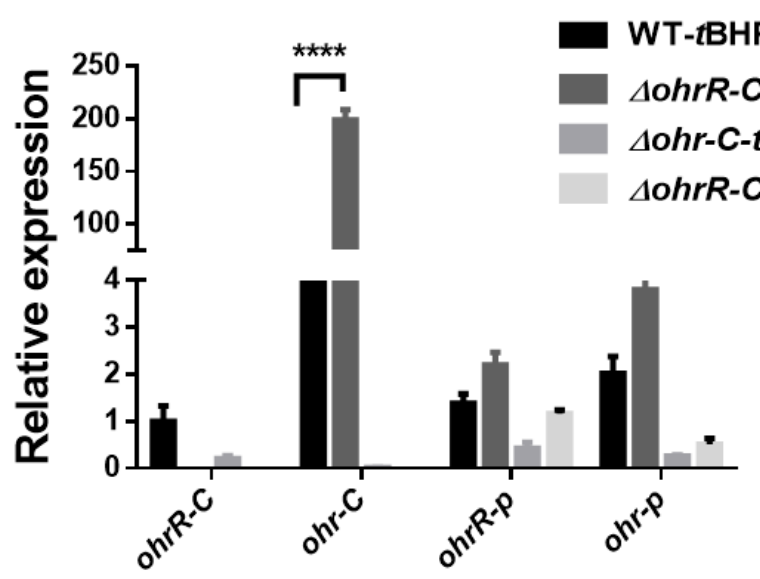

(C)

Figure 4. Transcriptional expression of chromosomal ohrR-C-ohr-C and pMAC ohr-p-ohrR-p genes in different strains of A. baumannii ATCC 19606, as quantified by qRT-PCR. (A) Relative expression of chromosomal ohrR-C-ohr-C and pMAC ohr-p-ohrR-p genes in wild-type strains cultured in the presence (WT- $t$ BHP) or absence (WT) of $200 \mu \mathrm{M}$ of $t \mathrm{BHP}$ for $20 \mathrm{~min}$. Relative expression of chromosomal ohrR-C-ohr-C and pMAC ohr-p-ohrR-p genes in ohrR-C mutant ( $\Delta$ ohrR-C), ohr-C mutant $(\Delta o h r-C)$, and ohrR-C-ohr-C double mutant $(\Delta o h r R-C \Delta o h r-C)$ strains compared with wild-type strains in the absence 
(B) and presence (C) of $t$ BHP. These data were obtained from three independent experiments. Each sample was normalized using gyrase gene expression as an internal control. The expression of ohr $R-C$ gene in wild type was determined as 1 for comparison. Multiple-way ANOVA was used to determine the significance of each phase. ${ }^{* * * *}$ indicates $p<0.001$.

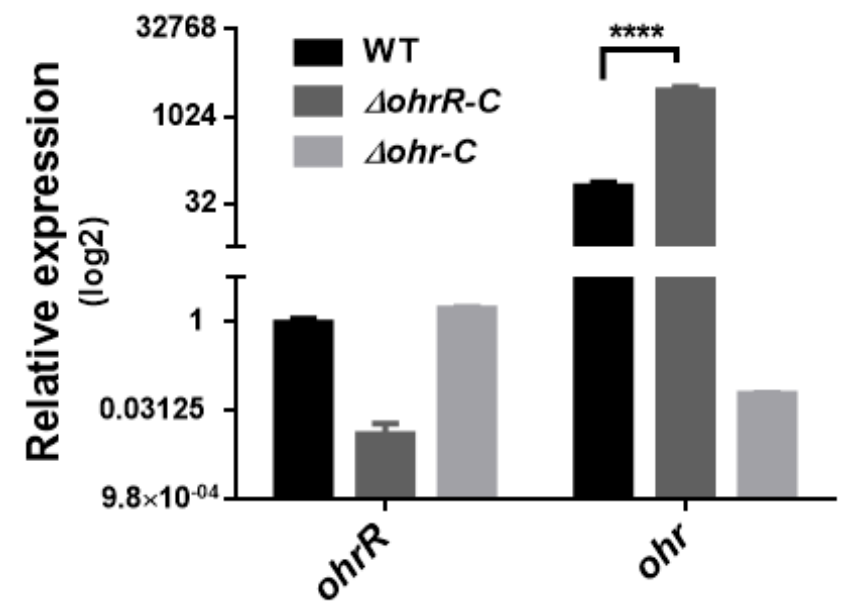

(A)

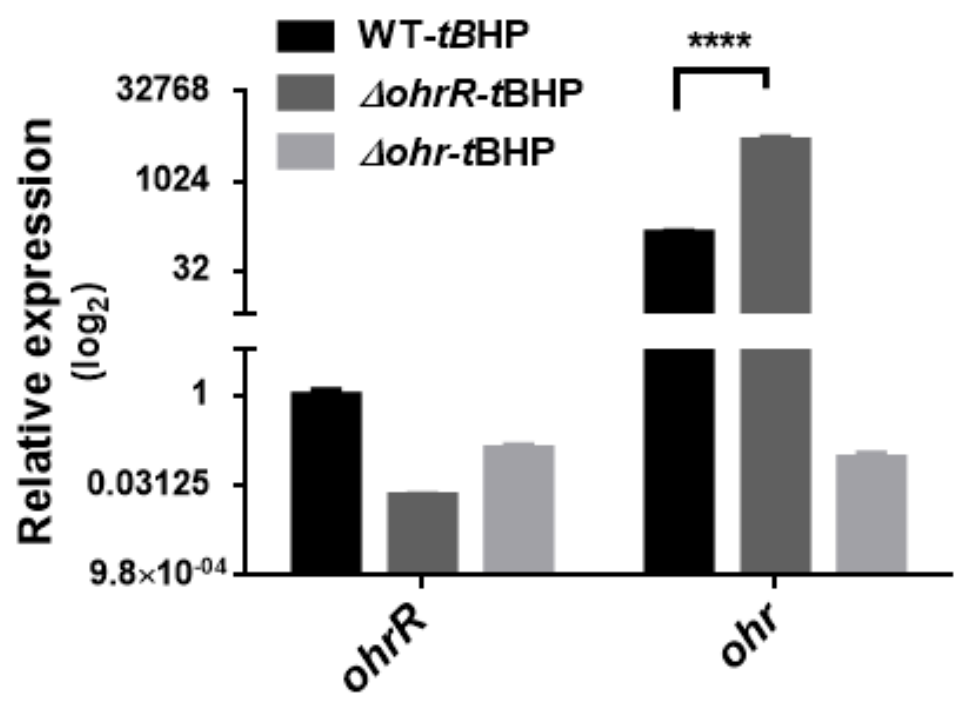

(B)

Figure 5. Transcriptional expression of chromosomal ohrR-C-ohr-C genes in different strains of $A$. baumannii ATCC 17978, as quantified by qRT-PCR. Relative expression of chromosomal ohrR-C-ohr-C genes in $o h r R-C$ mutant $(\Delta o h r R-C)$ and $o h r-C$ mutant $(\Delta o h r-C)$ strains compared with wild-type strains in the absence (A) and presence of $200 \mu \mathrm{M}$ of $t \mathrm{BHP}$ for $20 \mathrm{~min}$ (B). Each sample was normalized using gyrase gene expression as an internal control. The expression of $o h r R-C$ gene in wild type was determined as 1 for comparison. These data were obtained from three independent experiments. Multiple-way ANOVA was used to determine the significance of each phase. ${ }^{* * * *}$ indicates $p<0.0001$.

A disk diffusion assay was conducted to assess $t$ BHP resistance for each strain of $A$. baumannii 19606. The zone of inhibition was diminished in ohrR-C mutants as compared with wild-type (Figure 6A), and this observation concurs with the qRT-PCR results. A previous study has shown that the ohr-p-ohrR-p genes on pMAC contribute to organic peroxide resistance in A. baumannii 19606 [20], and to better ascertain the role of the pMAC genes, a chromosomal ohrR-C-ohr-C double mutant was generated by markerless allelic exchange, to create strains with ohr-p-ohrR-p only. We found that pMAC alone did not contribute to $t \mathrm{BHP}$ resistance (Figure 6A). Moreover, a disk diffusion assay conducted with 
ohrR-C and ohr-C single mutants of $A$. baumannii ATCC 17978 found that the ohr- $C$ single mutant had reduced resistance against $t \mathrm{BHP}$ (Figure $6 \mathrm{~B}$ ). These results further confirm the importance of $o h r-C$ to $t \mathrm{BHP}$ resistance.

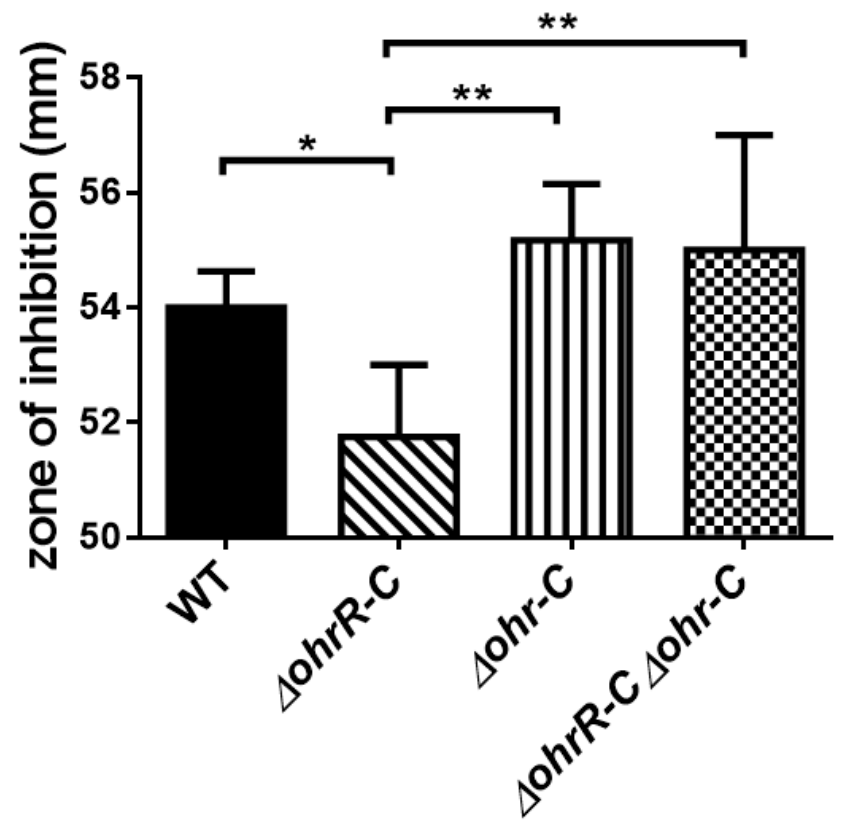

(A)

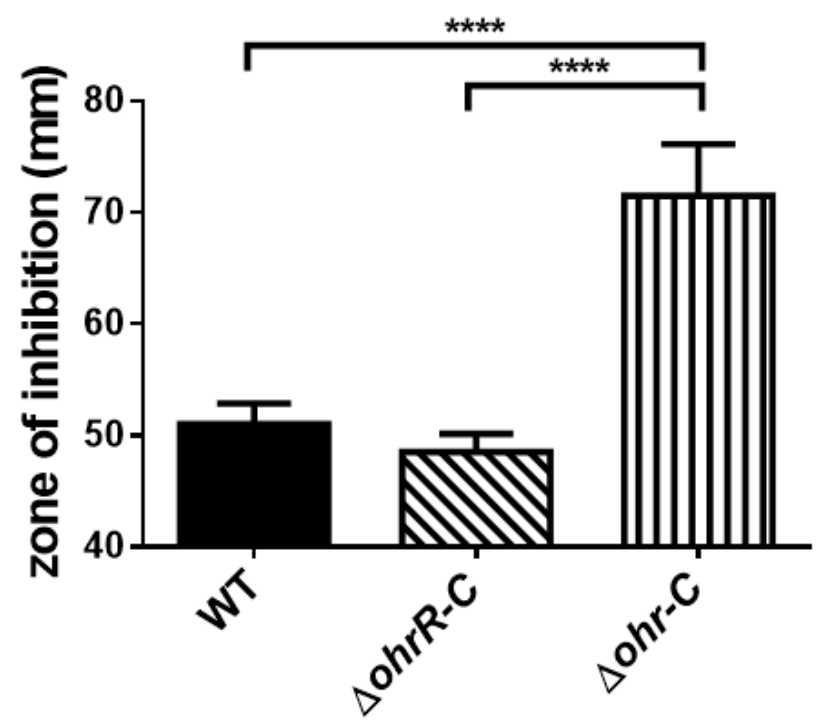

(B)

Figure 6. Disk diffusion assay for different strains of A. baumannii. (A) ATCC 19606 and (B) ATCC 17978 disk diffusion assay results. The zone of inhibition was determined after bacteria were treated with $135 \mu \mathrm{g}$ of $t \mathrm{BHP}$ for $12 \mathrm{~h}$. These data were obtained from three independent experiments. Multiple-way ANOVA was used to determine the significance of each phase. ${ }^{*}$ indicates $p<0.05$; ** indicates $p<0.01$; ${ }^{* * *}$ indicates $p<0.0001$.

\subsection{Binding of OhrR-C to the Promoter of the ohr-C and ohr- $p$ Genes}

To confirm that chromosomal OhrR-C suppressed ohr-C gene expression, EMSA was conducted to ascertain the direct binding of Ohr-C to the promoter region of the ohr-C gene. The putative OhrR-C box of A. baumannii, AAATXAT-14-ATXTATTT (Figure 7) contains an AT-rich motif that has been found in most of the DNA-binding sequences of OhrR-C 
homologs [7,13,29-31]. The entire 85-bp putative promoter region of the ohr-C gene was split into different fragments (Figure 7). $\mathrm{P}_{\text {ohr-1 }}$ and $\mathrm{P}_{\text {ohr-2 }}$ divided this region into two parts, each covering half of the promoter region. $\mathrm{P}_{\text {ohr-3 }}$ is 18-bp shorter than $\mathrm{P}_{\text {ohr }}$ (Figure 8A). We incubated $50 \mathrm{nM}$ of DNA probes with recombinant OhrR-C purified from an E. coli overexpression strain. The results showed that only $\mathrm{P}_{\mathrm{ohr}-3}$ and $\mathrm{P}_{\mathrm{ohr}}$ could be bound by $600 \mathrm{nM}$ of OhrR-C, with a mobility shift in electrophoresis observed (Figure 8A). We then used different concentrations of OhrR-C to interact with $\mathrm{P}_{\text {ohr }}$. Results revealed that a mobility shift could be observed with just $400 \mathrm{nM}$ of OhrR-C mixed with DNA (Figure 8B, lane 4). Increasing OhrR-C concentration to $600 \mathrm{nM}$ led to a significant mobility shift (Figure $8 \mathrm{~B}$, lane 6). The DNA/protein complexes became trapped in electrophoresis wells when the amount of OhrR-C exceeded $800 \mathrm{nM}$ (Figure 8B, lane 8).

A.

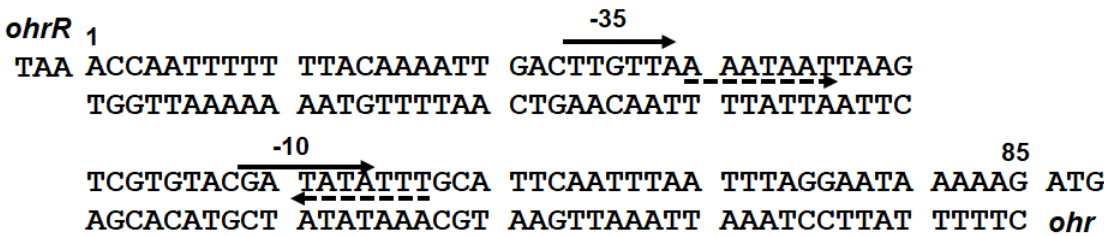

B.

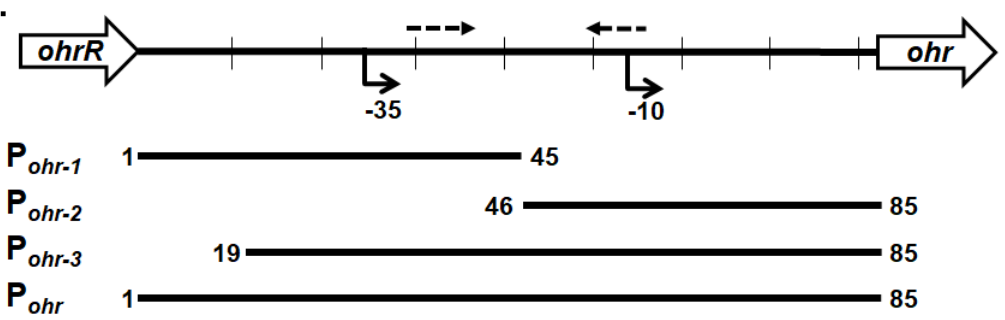

Figure 7. Genetic organization and intergenic sequences for chromosomal ohrR-C and ohr-C genes. (A) Intergenic sequences between the chromosomal $o h r R-C$ and $o h r-C$ genes. The numbers indicate positions relative to the stop codon of $o h r R$. Arrows with dashed lines indicate the putative inverted repeats. (B) Genetic organization and relative position of probes for EMSA.

Recombinant chromosomal OhrR-C was also used to test binding capability with the promoter region of ohr-p on pMAC. A mobility shift was observed when $1 \mu \mathrm{M}$ of OhrR-C was mixed with DNA (Figure $8 \mathrm{C}$, lane 4 ). Increasing OhrR-C concentration to $1.4 \mu \mathrm{M}$ led to a significant mobility shift (Figure $8 \mathrm{C}$, lane 5 ), and the DNA/protein complexes became trapped in the well when the amount of OhrR-C exceeded $2.6 \mu \mathrm{M}$ (Figure 8C, lane 8). Taken together, recombinant chromosomal OhrR-C showed less affinity for the promoter region of ohr-p on pMAC, compared with chromosomal ohr-C. 


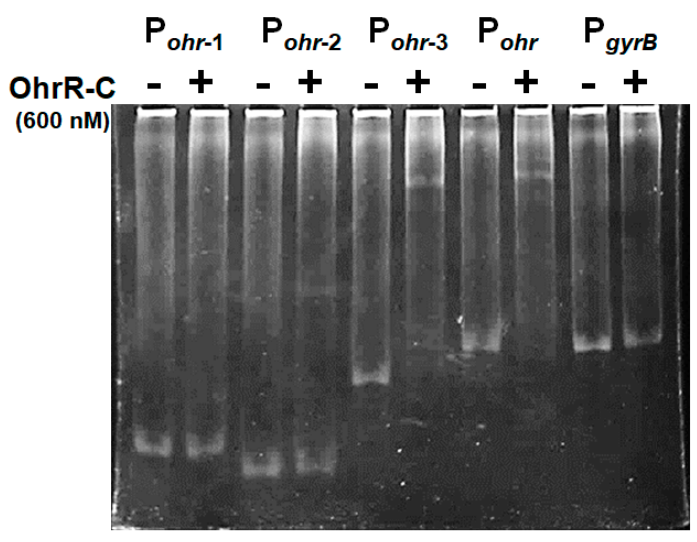

(A)

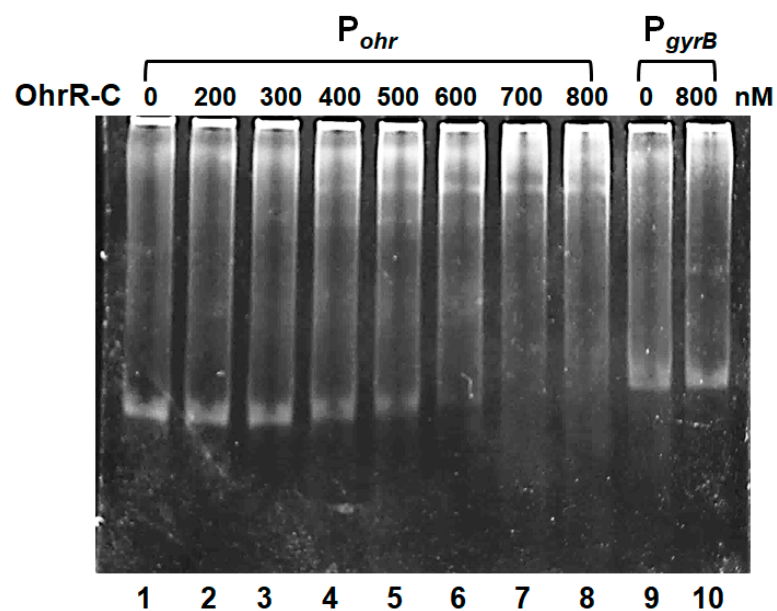

(B)

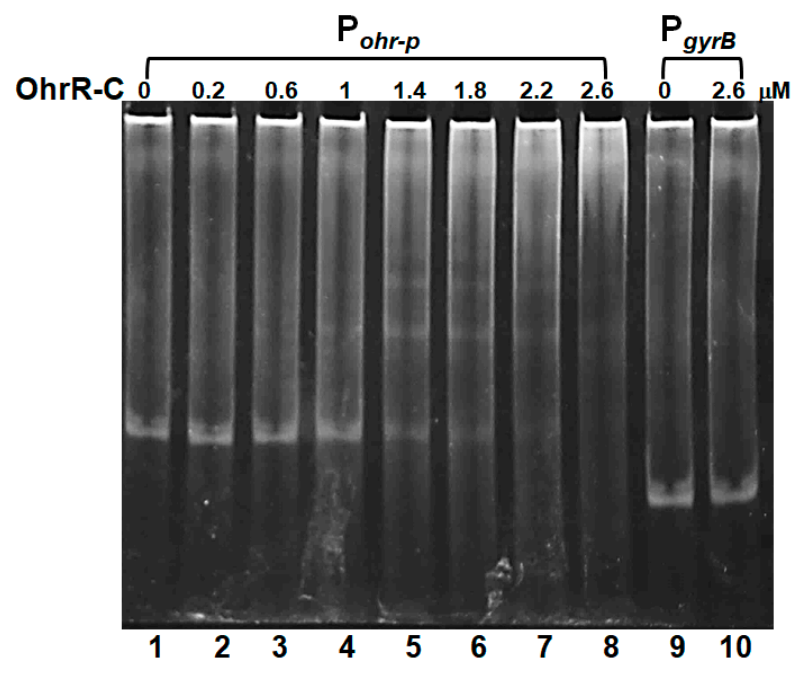

(C)

Figure 8. OhrR-C binds specifically to the chromosomal ohrR-ohr intergenic region and the ohr-p promoter region on pMAC. (A) OhrR-C (600 nM) incubated with different probes (50 nM). (B) $\mathrm{P}_{\text {ohr }}$ incubated with different concentrations of OhrR-C $(0-800 \mathrm{nM}) . \mathrm{P}_{g y r B}$ is a gyrase gene promoter that was incubated with or without $800 \mathrm{nM}$ of $\mathrm{OhrR}-\mathrm{C}$, to serve as a control. (C) $\mathrm{P}_{\text {ohr }-p}$ interaction with different concentrations of OhrR-C (0-2600 nM). $P_{\text {gyrB }}$ is a gyrase gene promoter that was also incubated with or without $2600 \mathrm{nM}$ of OhrR-C, to serve as a control. Concentrations of OhrR-C are indicated in the top row. 


\subsection{OhrR-C Suppressed Ohr-C Expression in E. coli}

We sought to examine the role of ohrR-C-ohr-C genes by cloning them into a pQE80L plasmid, and then transformed the plasmid into $E$. coli to ascertain whether gain of $t \mathrm{BHP}$ resistance functions could be observed in the transformants. We therefore cloned ohrR-C into pQE80L under the isopropyl $\beta$-D-1-thiogalactopyranoside (IPTG)-inducible T5 promoter with N-terminal 6-His fusion, to generate the pQE80L_OhrR-C plasmid. Subsequently, $o h r-C$ with its endogenous promoter was constructed downstream of $o h r R-C$, with a FLAGtagged C-terminal, to generate the pQE80L_OhrR-C_Ohr-C plasmid (Figure 9A). Each plasmid was transformed into the E. coli $\mathrm{DH} 5 \alpha$ strain for $t \mathrm{BHP}$ resistance tests. E. coli transformed with an empty $\mathrm{pQE} 80 \mathrm{~L}$ showed no difference in $t \mathrm{BHP}$ resistant properties, but in transformants with OhrR-C induced by $1 \mathrm{mM} \mathrm{IPTG}$, increased $t \mathrm{BHP}$ sensitivity was observed, suggesting that OhrR-C may also suppress the $t \mathrm{BHP}$ resistance genes in $E$. coli. However, transformants with the ohr-C gene had reduced inhibition zones, indicative of increased $t \mathrm{BHP}$ resistance; but following the induction of OhrR-C expression, $\mathrm{Ohr}-\mathrm{C}$ was subsequently repressed, and increased $t$ BHP sensitivity was observed (Figure $9 \mathrm{~B}$ ). From this gain-of-function experiment, it was observed that OhrR-C was able to regulate the expression of the ohr-C gene derived from A. baumannii.

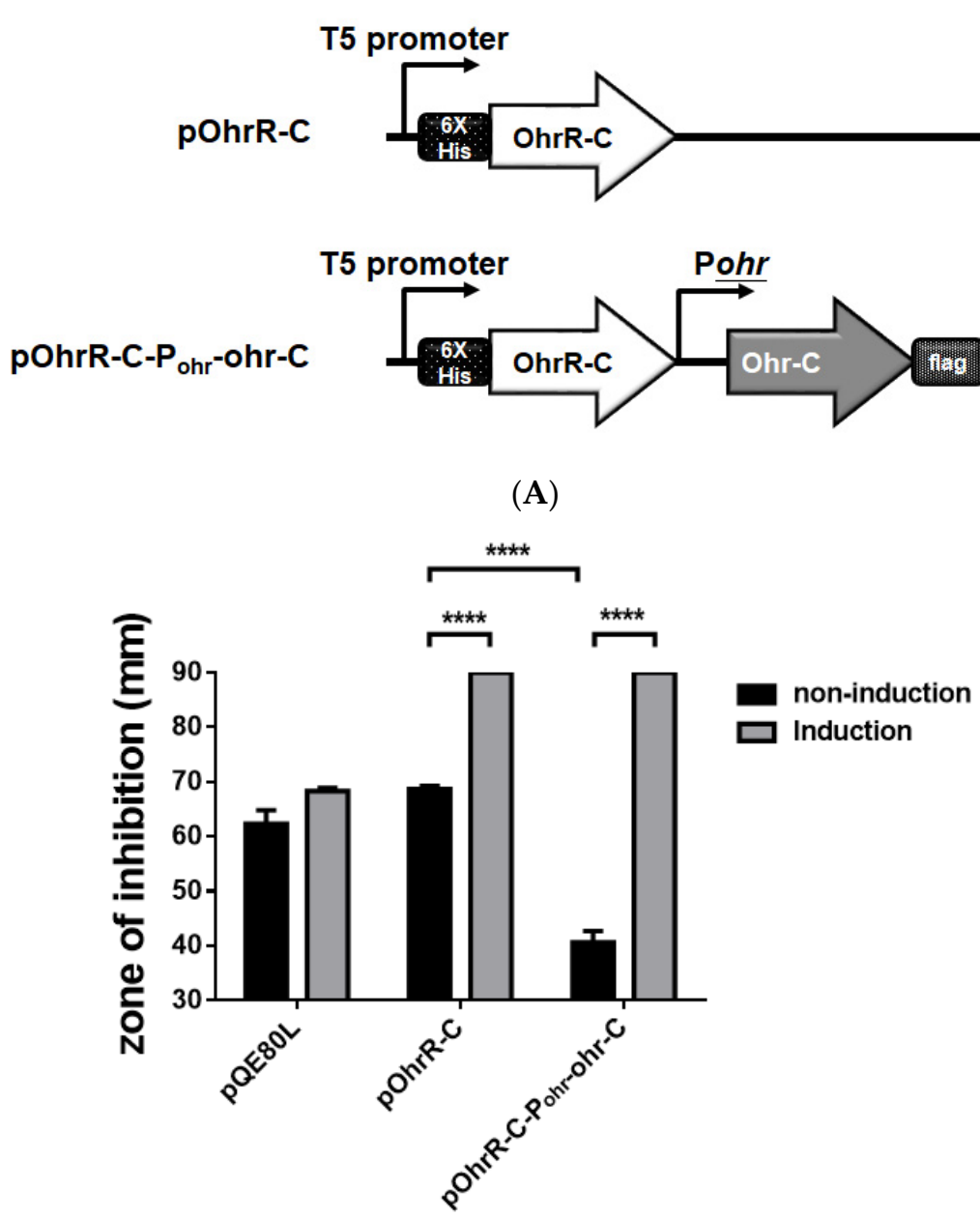

(B)

Figure 9. Genetic organization and disk diffusion assay for the gain of function assay in E. coli. (A) Genetic organization of OhrR-C expressing strains and OhrR-C-Ohr-C expressing strains. (B) Disk diffusion assay. Different $E$. coli strains without (black bar) or with (gray bar) $1 \mathrm{mM}$ IPTG induction. Cultures were treated with $135 \mu \mathrm{g}$ tBHP for $12 \mathrm{~h}$. Multiple-way ANOVA was used to determine the significance of each phase. ${ }^{* * *}$ indicates $p<0.0001$. 


\subsection{The ohrR-C Mutant Demonstrated Decreased Virulence in Galleria mellonella}

To assess the overall virulence of $o h r-C$ and $o h r R-C$ mutants compared with wild-type, G. mellonella larvae $(\mathrm{n}=10)$ were respectively incubated with $5 \times 10^{6}$ colony-forming units (CFU) of each A. baumannii strain. We observed that ohrR-C mutants displayed significantly greater virulence in G. mellonella as compared to wild-type, ohr-C single mutants, and ohrR$C$-ohr-C double mutants, with only $10 \%$ larvae survival at $72 \mathrm{~h}$ compared to $70 \%$ survival for the other three strains. However, ohr-C single mutants and ohrR-C-ohr-C double mutants retained $60 \%$ virulence in G. mellonella at $96 \mathrm{~h}$, indicating that the ohr-p-ohrR-p genes on pMAC may play a role in virulence for G. mellonella (Figure 10A). A survival assay was performed with A. baumannii ATCC 17978 strains without pMAC, to better understand the importance of chromosomal ohrR-C and ohr-C for virulence against $G$. mellonella. The results showed that, while wild-type strains killed all infected larvae within $24 \mathrm{~h}$, the ohr-C single mutants had significantly reduced virulence, even at $96 \mathrm{~h}$ after infection (Figure 10B). The results suggest that the chromosomal ohr-C gene plays an important role in A. baumannii virulence toward G. mellonella, and this may have implications for other hosts as well.

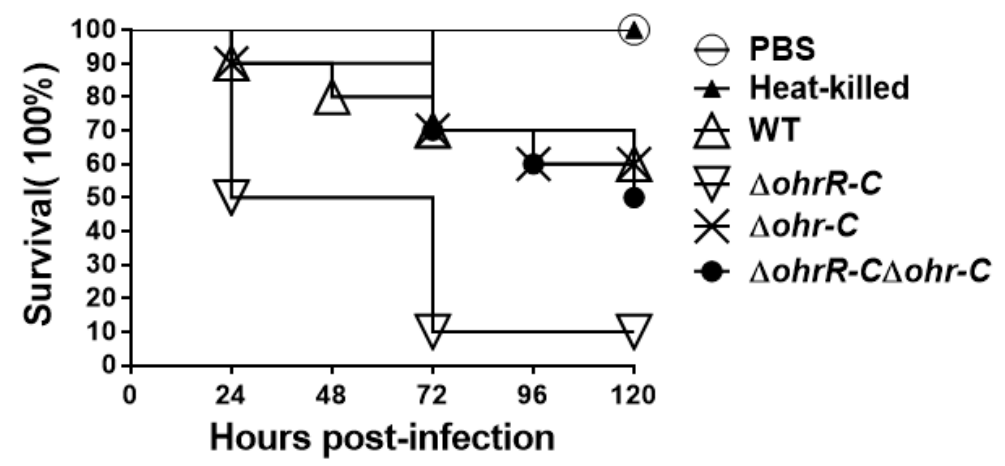

(A)

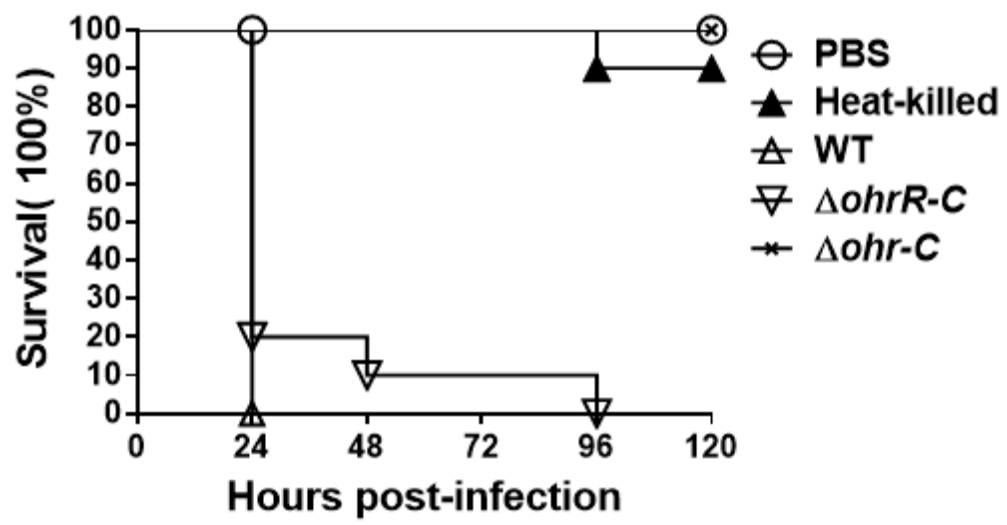

(B)

Figure 10. G. mellonella survival curve following infection with A. baumannii wild-type and mutants. Larvae were infected with $5 \times 10^{6}$ CFU of wild-type or mutant (A) ATCC 19606 or (B) ATCC 17978 strains. PBS was used as the buffer. Heat-killed indicates wild-type bacteria treated at $100{ }^{\circ} \mathrm{C}$ for $10 \mathrm{~min}$. WT, wild type bacteria; $\Delta$ ohrR-C, ohrR-C mutant; $\Delta$ ohr $-\mathrm{C}$, ohr-C mutant; $\Delta$ ohrR-C $\Delta$ ohr $-\mathrm{C}$, ohrR-C-ohr-C double mutant. The curve represents a single experiment performed with 10 larvae.

\section{Discussion}

The Ohr protein is a thiol-dependent peroxidase that plays a major role in the response of bacteria against organic peroxide [29]. Most bacteria harbor at least one Ohr protein $[30,31]$. In this study, both chromosomal and plasmid ohr genes were identified in A. baumannii 19606. The promoter regions of both ohr genes can be bound by OhrR, albeit with varying affinity. Other examples of bacteria with more than one ohr gene have 
previously been identified. In B. subtilis, two homologs of Ohr, OhrA and OhrB, have been identified and studied [7]. OhrR is capable of repressing ohrA expression, while ohrB is unaffected [7]. However, in P. aeruginosa, homologous OhrR and OspR have been shown to act as regulatory switches in response to oxidative stress [32]. OspR regulates $g p x$, which encodes a glutathione peroxidase. In an $\operatorname{ssp} R$ mutant, in which $g p x$ is depressed, the induction of ohr expression by oxidative stress is reduced. Similarly, in an ohrR mutant, where $o h r$ is derepressed, organic hydroperoxide induction of $g p x$ is reduced [32].

Several thousand strains of A. baumannii have been sequenced, and some of these have been reported to harbor plasmids [20]. Genomic sequence analysis revealed that pM1301-3 of Acinetobacter sp. M131 and a plasmid in A. baumannii ab736 had comparable length and shared high sequence similarity with pMAC of A. baumannii ATCC 19606. All of these plasmids contained ohr-p-ohrR-p genes. Multi-sequence alignment also revealed that ohr-p-ohrR-p genes can be found in pALWS1.1 of Acinetobacter lwoffii VS15 and p1AsACE of Acinetobacter schindleri ACE. These observations suggest that $A$. baumannii may gain these genes through horizontal gene transfer. Based on our observation of growth curves for the ohr-C mutant of A. baumannii ATCC 17978, chromosomal ohr-C not only plays a role in generating resistance to OHPs but is also associated with rapid bacterial growth (Figure 3B). However, this was not observed for the ohr-C single mutant and ohrR-C-ohr-C double mutant of A. baumannii ATCC 19606 (Figure 3A), and this may be due to the complementary effect of the ohr-p-ohrR-p genes on pMAC.

Both A. baumannii ATCC 19606 [33] and A. baumannii ATCC 17978 [34] harbor resistance to multiple antibiotics, but with different resistance profiles. For example, previous research [34] and our unpublished data demonstrate that A. baumannii ATCC 19606 has higher minimal inhibitory concentrations (MIC) with tigecycline $(2 \mathrm{mg} / \mathrm{L})$, imipenem $(2 \mathrm{mg} / \mathrm{L})$, and colistin $(1 \mathrm{mg} / \mathrm{L})$, as compared to A. baumannii ATCC 17978 [34]. Some bactericidal antibiotics operate through the production of highly deleterious hydroxyl radicals in bacteria [35]. Surprisingly, lipoyl groups are essential for parasite survival in host cells [36,37] and for virulence [38]. Taken together, our findings suggest that $A$. baumannii ATCC 19606 may have gained PMAC via horizontal gene transfer, and this strain exhibits higher MIC to antibiotics not only because of the antibiotic resistance genes encoded on PMAC, but also because two sets of ohr genes are present in the chromosomal DNA and pMAC respectively. This can increase resistance to OHPs and hydroxyl radicals from bactericidal antibiotics, thereby increasing virulence. Future research into novel antibacterial therapies that target these ohr genes may therefore be warranted.

\section{Conclusions}

A. baumannii has gained increasing attention in recent years due to its role in nosocomial infections. The strains examined in this study all harbor resistance to multiple antibiotics, and considering that some antibiotics act by producing hydroxyl radicals that are highly deleterious, it is possible that aside from antibiotic resistance genes present on plasmids, the presence of $o h r$ genes on plasmids and chromosomal DNA can contribute to bacterial viability and resistance as well. Therefore, a study of the ohr genes and their functions may have important implications for understanding bacterial resistance and preventing or addressing nosocomial infections.

Supplementary Materials: The following are available online at https://www.mdpi.com/2076-260 7/9/3/629/s1, Figure S1: Amino acid identity of Ohr and OhrR proteins.

Author Contributions: Conceived and designed the experiment, H.-Y.S. and G.-H.L.; performed the experiment, S.-J.C. and H.-Y.S.; analyzed the data, S.-J.C. and H.-Y.S.; wrote the paper, H.-Y.S. and G.-H.L. All authors have read and agreed to the published version of the manuscript.

Funding: This study was funded by Grant No. TCMF-SP 110-02 from Buddhist Tzu Chi Medical Foundation to Guang-Huey Lin. The funders had no role in study design, data collection and interpretation, or the decision to submit the work for publication. 
Data Availability Statement: All relevant data are within the manuscript and its supplementary information.

Conflicts of Interest: The authors declare no conflict of interest.

\section{References}

1. Hurst, J.K. What really happens in the neutrophil phagosome? Free Radic. Biol. Med. 2012, 53, 508-520. [CrossRef]

2. Ayala, A.; Munoz, M.F.; Arguelles, S. Lipid peroxidation: Production, metabolism, and signaling mechanisms of malondialdehyde and 4-hydroxy-2-nonenal. Oxid. Med. Cell Longev. 2014, 2014, 360438. [CrossRef] [PubMed]

3. Fang, F.C. Antimicrobial actions of reactive oxygen species. mBio 2011, 2, e00141-11. [CrossRef]

4. Cussiol, J.R.; Alegria, T.G.; Szweda, L.I.; Netto, L.E. Ohr (organic hydroperoxide resistance protein) possesses a previously undescribed activity, lipoyl-dependent peroxidase. J. Biol. Chem. 2010, 285, 21943-21950. [CrossRef]

5. Si, Y.; Guo, D.; Deng, S.; Lu, X.; Zhu, J.; Rao, B.; Cao, Y.; Jiang, G.; Yu, D.; Zhong, Z.; et al. Ohr and OhrR Are Critical for Organic Peroxide Resistance and Symbiosis in Azorhizobium caulinodans ORS571. Genes 2020, 11, 335. [CrossRef]

6. Cussiol, J.R.; Alves, S.V.; de Oliveira, M.A.; Netto, L.E. Organic hydroperoxide resistance gene encodes a thiol-dependent peroxidase. J. Biol. Chem. 2003, 278, 11570-11578. [CrossRef]

7. Fuangthong, M.; Atichartpongkul, S.; Mongkolsuk, S.; Helmann, J.D. OhrR is a repressor of ohrA, a key organic hydroperoxide resistance determinant in Bacillus subtilis. J. Bacteriol. 2001, 183, 4134-4141. [CrossRef]

8. Das, K.; Garnica, O.; Dhandayuthapani, S. Utility of OhrR-Ohr system for the expression of recombinant proteins in mycobacteria and for the delivery of M. tuberculosis antigens to the phagosomal compartment. Tuberculosis 2019, 116S, S19-S27. [CrossRef]

9. Will, W.R.; Fang, F.C. The evolution of MarR family transcription factors as counter-silencers in regulatory networks. Curr. Opin. Microbiol. 2020, 55, 1-8. [CrossRef] [PubMed]

10. Fuangthong, M.; Helmann, J.D. The OhrR repressor senses organic hydroperoxides by reversible formation of a cysteine-sulfenic acid derivative. Proc. Natl. Acad. Sci. USA 2002, 99, 6690-6695. [CrossRef] [PubMed]

11. Lee, J.W.; Soonsanga, S.; Helmann, J.D. A complex thiolate switch regulates the Bacillus subtilis organic peroxide sensor OhrR. Proc. Natl. Acad. Sci. USA 2007, 104, 8743-8748. [CrossRef]

12. Warmbold, B.; Ronzheimer, S.; Freibert, S.A.; Seubert, A.; Hoffmann, T.; Bremer, E. Two MarR-Type Repressors Balance Precursor Uptake and Glycine Betaine Synthesis in Bacillus subtilis to Provide Cytoprotection Against Sustained Osmotic Stress. Front. Microbiol. 2020, 11, 1700. [CrossRef]

13. Pande, A.; Veale, T.C.; Grove, A. Gene regulation by redox-sensitive Burkholderia thailandensis OhrR and its role in bacterial killing of Caenorhabditis elegans. Infect. Immun. 2018. [CrossRef] [PubMed]

14. Baumann, P.; Doudoroff, M.; Stanier, R.Y. A study of the Moraxella group. II. Oxidative-negative species (genus Acinetobacter). J. Bacteriol. 1968, 95, 1520-1541. [CrossRef] [PubMed]

15. Antunes, L.C.; Visca, P.; Towner, K.J. Acinetobacter baumannii: Evolution of a global pathogen. Pathog. Dis. 2014, 71, 292-301. [CrossRef] [PubMed]

16. Bergogne-Berezin, E.; Decre, D.; Joly-Guillou, M.L. Opportunistic nosocomial multiply resistant bacterial infections-their treatment and prevention. J. Antimicrob. Chemother. 1993, 32 (Suppl. A), 39-47. [CrossRef]

17. Bergogne-Berezin, E.; Towner, K.J. Acinetobacter spp. as nosocomial pathogens: Microbiological, clinical, and epidemiological features. Clin. Microbiol. Rev. 1996, 9, 148-165. [CrossRef] [PubMed]

18. Villegas, M.V.; Hartstein, A.I. Acinetobacter outbreaks, 1977-2000. Infect. Control Hosp. Epidemiol. 2003, 24, 284-295. [CrossRef]

19. Bouvet, P.J.; Grimont, P.A. Taxonomy of the genus Acinetobacter with the recognition of Acinetobacter baumannii sp. nov., Acinetobacter haemolyticus sp. nov., Acinetobacter johnsonii sp. nov., and Acinetobacter junii sp. nov. and emended descriptions of Acinetobacter calcoaceticus and Acinetobacter lwoffii. Int. J. Syst. Bacteriol. 1986, 36, 228-240.

20. Dorsey, C.W.; Tomaras, A.P.; Actis, L.A. Sequence and organization of pMAC, an Acinetobacter baumannii plasmid harboring genes involved in organic peroxide resistance. Plasmid 2006, 56, 112-123. [CrossRef]

21. Bertani, G. Studies on lysogenesis. I. The mode of phage liberation by lysogenic Escherichia coli. J. Bacteriol. 1951, 62, 293-300. [CrossRef] [PubMed]

22. Herigstad, B.; Hamilton, M.; Heersink, J. How to optimize the drop plate method for enumerating bacteria. J. Microbiol. Methods. 2001, 44, 121-129. [CrossRef]

23. Schäfer, A.; Tauch, A.; Jager, W.; Kalinowski, J.; Thierbach, G.; Puhler, A. Small mobilizable multi-purpose cloning vectors derived from the Escherichia coli plasmids pK18 and pK19: Selection of defined deletions in the chromosome of Corynebacterium glutamicum. Gene 1994, 145, 69-73. [CrossRef]

24. Beeton, M.L.; Chalker, V.J.; Maxwell, N.; Kotecha, S.; Spiller, O.B. Concurrent titration and determination of antibiotic resistance in ureaplasma species with identification of novel point mutations in genes associated with resistance. Antimicrob. Agents. Chemother. 2009, 53, 2020-2027. [CrossRef]

25. Lin, H.R.; Shu, H.Y.; Lin, G.H. Biological roles of indole-3-acetic acid in Acinetobacter baumannii. Microbiol. Res. 2018, 216, 30-39. [CrossRef]

26. Shu, H.Y.; Lin, L.C.; Lin, T.K.; Chen, H.P.; Yang, H.H.; Peng, K.C.; Lin, G.H. Transcriptional regulation of the iac locus from Acinetobacter baumannii by the phytohormone indole-3-acetic acid. Antonie Van Leeuwenhoek. 2015. [CrossRef] [PubMed] 
27. Wang-Kan, X.; Blair, J.M.A.; Chirullo, B.; Betts, J.; La Ragione, R.M.; Ivens, A.; Ricci, V.; Opperman, T.J.; Piddock, L.J.V. Lack of AcrB Efflux Function Confers Loss of Virulence on Salmonella enterica Serovar Typhimurium. mBio 2017, 8, e00968-17. [CrossRef]

28. Tsai, C.J.; Loh, J.M.; Proft, T. Galleria mellonella infection models for the study of bacterial diseases and for antimicrobial drug testing. Virulence 2016, 7, 214-229. [CrossRef]

29. Chuchue, T.; Tanboon, W.; Prapagdee, B.; Dubbs, J.M.; Vattanaviboon, P.; Mongkolsuk, S. ohrR and ohr are the primary sensor/regulator and protective genes against organic hydroperoxide stress in Agrobacterium tumefaciens. J. Bacteriol. 2006, 188, 842-851. [CrossRef]

30. Oh, S.Y.; Shin, J.H.; Roe, J.H. Dual role of OhrR as a repressor and an activator in response to organic hydroperoxides in Streptomyces coelicolor. J. Bacteriol. 2007, 189, 6284-6292. [CrossRef]

31. Saikolappan, S.; Das, K.; Dhandayuthapani, S. Inactivation of the organic hydroperoxide stress resistance regulator OhrR enhances resistance to oxidative stress and isoniazid in Mycobacterium smegmatis. J. Bacteriol. 2015, 197, 51-62. [CrossRef]

32. Atichartpongkul, S.; Vattanaviboon, P.; Wisitkamol, R.; Jaroensuk, J.; Mongkolsuk, S.; Fuangthong, M. Regulation of Organic Hydroperoxide Stress Response by Two OhrR Homologs in Pseudomonas aeruginosa. PLoS ONE 2016, 11, e0161982. [CrossRef]

33. Qi., L.; Li, H.; Zhang, C.; Liang, B.; Li, J.; Wang, L.; Du, X.; Liu, X.; Qiu, S.; Song, H. Relationship between Antibiotic Resistance, Biofilm Formation, and Biofilm-Specific Resistance in Acinetobacter baumannii. Front. Microbiol. 2016, 7, 483. [CrossRef] [PubMed]

34. Fernando, D.M.; Khan, I.U.; Patidar, R.; Lapen, D.R.; Talbot, G.; Topp, E.; Kumar, A. Isolation and Characterization of Acinetobacter baumannii Recovered from Campylobacter Selective Medium. Front. Microbiol. 2016, 7, 1871. [CrossRef]

35. Kohanski, M.A.; Dwyer, D.J.; Hayete, B.; Lawrence, C.A.; Collins, J.J. A common mechanism of cellular death induced by bactericidal antibiotics. Cell 2007, 130, 797-810. [CrossRef] [PubMed]

36. O'Riordan, M.; Moors, M.A.; Portnoy, D.A. Listeria intracellular growth and virulence require host-derived lipoic acid. Science 2003, 302, 462-464. [CrossRef]

37. Allary, M.; Lu, J.Z.; Zhu, L.; Prigge, S.T. Scavenging of the cofactor lipoate is essential for the survival of the malaria parasite Plasmodium falciparum. Mol. Microbiol. 2007, 63, 1331-1344. [CrossRef] [PubMed]

38. Smith, A.W.; Roche, H.; Trombe, M.C.; Briles, D.E.; Hakansson, A. Characterization of the dihydrolipoamide dehydrogenase from Streptococcus pneumoniae and its role in pneumococcal infection. Mol. Microbiol. 2002, 44, 431-448. [CrossRef] 